\title{
E-module for prevention of sexual harrasment in adolescent
}

\author{
Fira Ramli ${ }^{1}$, Riska Ahmad ${ }^{2}$, Yarmis ${ }^{3}$ \\ ${ }^{123}$ Universitas Negeri Padang, Padang - Indonesia, (firafira.ramli@gmail.com)
}

\begin{abstract}
Adolescence has a task to accomplish in order to accept the changes that occur. Encouragement achieves the full developmental task of mature sexual adolescence that comes from teenage interest and curiosity about sexuality. However, adolescents vent their curiosity to physical behavior that is part of sexual harassment. The high level of negative behavior toward sex this the attention of educators in preventing and overcoming them. Guidance and Counseling in schools has a preventive function, whereby Counselors can guide clients against self-harmful behavior with varied and flexible behaviors and techniques. Modules with high adaptability to the development of science and technology in the form of electronic module (e-module) can be a media service Counselor. E-module is a user manual in digital version that can be opened by using electronic device. The module may obtain Counselors in the form of services in a certain format.
\end{abstract}

Keywords: E-module, sexual harassment, adolescent

\section{Introduction}

Adolescence is a period of change and has a developmental task that must be met in order to effectively juvenile to adult life. Encouragement in achieving the developmental tasks associated with adolescent sexual maturation. Psychologically the adolescent phase, there are two important aspects that teens are expected to find the orientation of sexuality and youth are expected to receive and develop the role of sex as well as certain abilities according to gender (Wardhani, 2012). However, a high curiosity makes adolescents to vent their curiosity to the physical behavior (such as touching, kissing, patting, pinching, or physical violence such as rape, etc.).

Degrading sexual attitudes are part of the sexual harassment Sexual harassment can result in difficulty in performing daily activities and may cause a risk to health and safety. Hill \& Kearl (2011), almost half of the students surveyed had experienced some form of sexual harassment such as verbal abuse (comments, jokes or unwanted sexual gestures) and physical abuse as well as the majority of students said that it a negative impact on them. Bahri, Syamsu \& Fajriani (2015), the rate of sexual abuse in Aceh majority of victims are children and young women under the age of 18 years, still a student, family socioeconomic status in the lower middle. Teens at risk of becoming victims of sexual abuse by various factors.

Adolescent need to adjust the distribution of sexual needs within the acceptance of social environment that does not violate the moral values of society and religion so free from the 
psychosexual anxiety. Teens need to get the right information about sex through sex education and responsibly. Correct sexual knowledge possessed teenagers can direct their sexual behavior on things that are positive and responsible (Wardhani, 2012). Lack of information about sexuality can lead students to become perpetrators or victims of sexual abuse.

Sex education in an effort to avoid sexual harassment. Comprehensive sex education can benefit and results counter the effects of drug use, risky sex, and encouraging positive adolescent sexual health (Kouyoumdjian \& Guzman, 2013). There are several parties involved in sex education one school. Suleiman et al (2015), school support adolescent sexual and reproductive health for life. The school is competent enough parties to supplement the knowledge in preventing sexual abuse in adolescents

The counselor as part of the school's role in providing services to prevent sexual harassment, one of them in the service information. Hikmawati, Fenti (2012: 16), guidance and counseling in schools have a function, preventive the function relating to anticipating problems that may occur or unexpected behavior and seek to prevent it. Service information needs a very high level.

Tohirin (2015: 144), some of the techniques that can be used for information services is through electronic and non-electronic media. Modules are high adaptable to science and technology can be a media counselor to carry out services for students should be able to be independent and self control in developing their potential. Electronic module (E-module) is a handbook in digital version, where the book E-module BK teacher can facilitate in providing services to students in the classical style. The e-module design adapted to the material services to be provided..

\section{Adolescent}

Adolescent can be from various points of view according to law, physical development, social, psychology, and society view in general. Fatimah (2008: 167), the concept of juvenile in law is only visible in the marriage law of 16 years for women and 19 years for men because adolescents are not from the legal field but social science, from the physical development of today's teenagers fasting where the female children experience menstruation and boys have wet dreams, from the social nervous factors of the process of changing the condition of "entropy" (uncompleted awareness), to the condition of negentropy, and adolescents to the Indonesian community has a boundary of 11-24 years and unmarried. Adolescence is strongly influenced by individual differences, a certain age alone is not enough to know whether a stage of new development, has or has not started.

Each phase of the development has a series of tasks that must be met by the development of adolescents. Adolescence has developmental tasks that must be met and implemented to prepare for the next period, in order not to fail, which can grow unhappiness, disagreements and young people experiencing difficulties in the execution of other tasks in the future. The task of adolescent development in achieving good relations with peers and social role as male or female adolescent developmental, that teens achieve new, more mature relationships with peers both men and women. In essence, the task of teenagers studying its role as a woman or a man, become an adult among adults, learning to lead without emphasizing others, because sexual maturity is achieved during adolescence where sex appeal that needs to be dominant in the lives of teenagers and young women are generally more precocious than young men.

\section{Adolescent Sexual Harassment}

Sexual harassment is included in sexually deviant behavior that can occur in adolescence. Sexual harassment is any form of sexually suggestive behavior taken unilaterally and not expected by people who were subjected to cause a negative reaction: embarrassment, anger, irritability and so in those who are victims of abuse. 
Forms of sexual harassment in Sumera, Marcheyla (2013), ranging from verbal expressions (comments, jokes and so on), behavior (pinch, fingering, menus, hugging, etc.), showing pornographic pictures, assault and coercion such as, forced to kiss or hug, threatened to complicate the woman when it refused to provide sexual services, to rape. Many forms of sexual abuse cases, but teens do not understand that the actions of others who make themselves uncomfortable with the treatment are part of the sexual harassment.

Bahri \& Fajriani (2015), the causes of sexual abuse is the lack of parental supervision of children, decreased morale actors and economic factors, and the psychological impact experienced by victims of sexual abuse are the victims tend to be aloof, socially isolated, excluded from school, blame yourself alone, and prolonged trauma. Wardhani \& Lestari (2007), the traumatic event after experiencing violence or sexual harassment can lead to mental disorders, that is PTSD, which levels of post-traumatic stress disorder vary depending on the severity of the incident affects the psychological condition of the victim. Many consequences caused by sexual abuse as a mental health problem form depression or anxiety that lasts longer, or post-traumatic stress syndrome. And there is also a psychological impact / other physiological ie panic attacks, anxiety, sleep disorders, blaming themselves, difficulty concentrating, headaches, loss of motivation, forget time, feeling betrayed, anger and to thoughts of suicide.

\section{Discussion}

\section{E-Modul}

Teachers do not directly teach or teach something to the students face to face, but enough with the module. Mulyasa (2004:43) that the module is a process of learning about a specific competency unit that is arranged in a systematic, operational and directional used by students and accompanied with usage guidelines for teachers. The module is also called the media for independent study because it has been equipped with instructions for self-study. That is, the reader can do without the presence of the teaching and learning activities directly. The design of the module into the e-modules to make educators and learners have easy and practical in accordance with the development of science and technology. E-Module is a tool or learning tool containing materials, methods, limitations, and how to evaluate systematically designed and attractive to achieve the expected competencies in accordance with the level of complexity electronically (part of the e-learning).

\section{Conclusions}

The adolescent who will be leaders in the future is very important in the beginning given information about sexuality to be spared the deviant sexual behavior. The development of science and technology into the differences in the process of school-based services. The importance of media that can be used by teachers and students make it easier to process the service as a module. The module should have a high adaptive towards science and technology. He designed a module with an electronic (e-module), can facilitate counselors in providing guidance and counseling services for the prevention of sexual abuse in adolescents. E-modules are designed with a variety of interesting content where there is an implementation plan services, material services, evaluation of student learning and video.

\section{References}

Bahri, Syamsu \& Fajriani. (2015). “Suatu Kajian Awal Terhadap Tingkat Pelecehan Seksual Di Aceh”. Universitas Syiah Kuala. 9, 50-65. 
Ballonoff Suleiman, A., Johnson, M., Shirtcliff, E. A., \& Galván, A. (2015). School-Based Sex Education and Neuroscience: What We Know About Sex, Romance, Marriage, and Adolescent Brain Development. Journal of School Health, 85(8), 567-574.

Fatimah, Enung. 2010. Psikologi Perkembangan (Perkembangan Peserta Didik). Bandung: Pustaka Setia

Hikmawati, Fenti. 2012. Bimbingan dan Konseling. Jakarta: Rajawali press

Hill, C., \& Kearl, H. (2011).Crossing the Line: Sexual Harassment at School.AAUW:Washington DC.

Kouyoumdijan, C., \& Guzman, B. L. (2013). Sex Education Justice: A Call for Comprehensive Sex Education and the Inclusion of Latino Early Adolescent Boys. Journal of the Association of Mexican American Educators, 7(1), 27-37.

Mulyasa. 2009. "Menjadi Guru Profesional (Menciptakan Pembelajaran Kreatif dan Menyenangkan)". Bandung: Remaja Rosdakarya.

Sumera, M. (2013). "Perbuatan Kekerasan/Pelecehan Seksual Terhadap Perempuan". Lex et Societatis, Vol. I/No.(3), 39-49.

Tohirin. 2015.Bimbingan dan Konseling di Sekolah dan Madrasah (Berbasis integrasi). Jakarta: Rajawali Perss

Wardhani, Dayne Trikora. (2012). "Perkembangan Seksual Remaja".Informasi, 17 (3) : 184-191

Wardhani, Y.F \& Lestari, W. (2006). “Gangguan Stres Pasca Trauma pada Korban Pelecehan Seksual dan Perkosaan". Surabaya: Pusat Penelitian dan Pengembangan Sistim dan Kebijakan Kesehatan 